UNIVERSITY

of DEBRECEN

FACULTY OF

HeAlth

NYÍREGYHÁZA

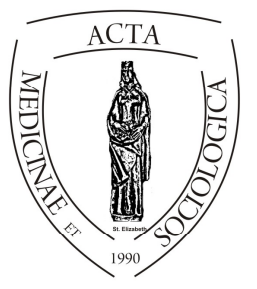

ACTA

MedSoc

VOLUME 5.

2014

\title{
Az anyagi depriváció jelenléte Nyíregyházán, 2012-ben
}

\author{
Szilicsány Éva Panna
}

Debreceni Egyetem, Egészségügyi Kar, Szociális Munka és Szociális Gazdaság mesterszak

\begin{abstract}
The theory and research of deprivation, being used for a few decades, has not been the most widely used method of researching poverty. This tendency is likely to turn soon since the European Union defines severe financial deprivation, as well as income poverty and employment intensity, as risk factors for social exclusion. In this study I intend to reveal deprivation and its accumulated severity among the inhabitants of Nyíregyháza by using the EU's coherent system of definitions and indicators. The outcomes of this study will provide an overall view of the living circumstances of the inhabitants in Nyíregyháza comparing them to Hungarian averages and that of the EU's. When examining financial deprivation, special attention is devoted to permanent poverty which derives from long-term lack of resources.
\end{abstract}

Key words: permanent poverty, living circumstance, severe financial deprivation, exclusion.

DOI: $10.19055 / \mathrm{ams} .2014 .5 / 12-13 / 5$ 


\section{Bevezetés}

A szegénységről általában mindenkinek a pénz, a jövedelem hiánya jut eszébe először, hiszen a rendelkezésre álló források jelentősen meghatározzák, hogy milyen javak szerezhetőek meg belőle, ami viszont erősen kihat életkörülményeinkre. A társadalomtudománnyal foglalkozók is ebből az alapvetésből indultak ki sokáig. Így a társadalmi egyenlőtlenségek, a szegénység kutatása, szinte tradicionálisan, a jövedelmi szegénység vizsgálatát jelentette, a legutóbbi időkig. Ez nem véletlen, hiszen a modern társadalmakban a rendelkezésre álló jövedelmek alkalmasak leginkább az egyéb erőforrások megszerzésére is, mint tudás, presztízs, társadalmi kapcsolatok. További érvként hozható fel, hogy egy adott jövedelemhatár meghúzásával, viszonylag könnyen, gyorsan, és pontosan meghatározhatóvá válik a szegénység. Kérdés, hogy a mérések pillanatában jövedelmi szempontból szegénynek számítók rendelkeznek-e olyan erőforrásokkal, melyek esélyt adnak számukra a peremhelyzetböl való kikerülésre, vagy megfosztottságuk, javaik hiánya oly mértékủ, hogy tartósan kirekesztődnek a társadalom föáramában való részvételből. A válasz megkeresésére több módszer is alkalmasnak látszik. Az időközönként elvégzett felmérésekből készíthető trendvizsgálat, illetve, azonos minta esetén, panelkutatás. Ez azonban rendkívül időigényes és költséges eljárás lehet. Költségkímélőbb és gyorsabb módszernek kínálkozik viszont a depriváció vizsgálata. A jövedelmekhez leginkább az anyagi depriváció kapcsolható, mely a fogyasztás oldaláról mutatja meg az anyagi javak olyan tartós hiányát, melyek folyamatos fennállása a társadalomból való kitaszítottsághoz, a kirekesztettséghez vezet.

A fenti gondolatmenet alapján, tanulmányomban arra teszek kísérletet, hogy feltérképezzem Nyíregyháza lakosságának életkörülményeit, az anyagi depriváció mentén. Arra keresve a választ, hogy a kirekesztettségnek ez a kockázata milyen mértékben van jelen a városban, a különböző deprivációs tényezők hogyan halmozódnak, milyen mértékben válnak súlyossá, és kiket érint leginkább. Miután a város Magyarország és az Európai Unió része, a teljes kép felvázolásához szükségessé válik relatív helyzetének megismerése is, az országhoz és az európai közösséghez viszonyítva. Első lépésként, a szegénység értelmezésével és kutatásával kapcsolatos elméleti és empirikus alapvetésekben kívánom elhelyezni a depriváció definícióját és módszertanát. Majd a Nyíregyháza város életminősége-háztartáspanel vizsgálat 2012. évi lekérdezése alapján rendelkezésre álló adatbázisból végzett statisztikai számításokat ismertetem, és elemzem. Eredményeim összehasonlíthatóságát, hazai és nemzetközi vonatkozásban, az Európai Unió által meghatározott definíciók és deprivációs tényezők alkalmazása biztosítja. 
Feltételezésem szerint, a nyíregyháziak anyagi megfosztottságaiban megmutatkozó helyzetek, az egyes anyagi deprivációt mérő elemi indikátorok, azok halmozódásának illetve a különböző jelzőszámok mentén való megoszlásának vonatkozásában, többségükben azonos tendenciát mutatnak a magyarországi és az európai uniós adatokkal. Mindamellett, hogy az arányokat tekintve, a magyarországi, és így feltételezhetően, a nyíregyházi anyagi depriváció nagyságendekkel magasabb, mint az európai uniós átlag. De bizonyára, a város földrajzi helyzetéből adódóan, kedvezőtlenebb tényezők is feltárulnak számunkra, mind az egyes deprivációs tényezőket, mind halmozódásukat tekintve, melyek további kérdéseket vetnek fel.

\section{Elméleti és empirikus alapvetések és értelmezések}

Míg a szegénység társadalmi tényként való elfogadása egyszerünek és kézenfekvőnek látszik, a meghatározására szolgáló elméleti és empirikus szakirodalom megismerése annál nehezebb feladat. Mint fogalom, és társadalmi jelenség, a szerint nyeri el értelmét, hogy a társadalmilag meghatározott minimum szintből, esetleg a többséghez való viszonyításból, vagy az egyén által megélt helyzetből indulunk ki. Az értelmezésekben való eligazodást tovább bonyolítja, hogy a jövedelmeket kívánjuk-e vizsgálni, vagy azt mondjuk, hogy a fogyasztás, az életkörülmények határozzák meg az egyének és csoportok helyét a társadalomban. Ehhez kapcsolódóan két további szempont is felmerül. Kérdés, hogy a rendelkezésre álló források, illetve megszerzett javak mely szintjénél kerül maghúzásra az a határvonal, ami a társadalom tagjait szegényekre és nem szegényekre osztja, és ezen felosztás statikus, vagy időben változik.

Mint láthatjuk, a szegénység témaköre, és értelmezése bonyolult. E labirintusba való tájékozódáshoz Spéder Zsolt (2002) munkáját használom vezérfonalként. A szegénység változó arcai - Tények és értelmezések címü könyv egyik jelentősége éppen az, hogy a szegénység megismeréséhez próbál támpontokat nyújtani, az eddig napvilágot látott szakirodalmi értelmezések egyfajta rendszerezésével. Ez olyan fogódzónak ígérkezik, melynek segítségével megkísérlem elhelyezni a deprivációt mint fogalmat, és mint empirikus kategóriát a szegénységdiskurzusokban.

A fentebb említett szerző, a klasszikus társadalmi struktúra- és rétegződéskutatásokból indul ki. Szerinte, a konfliktuselméleti és funkcionalista megközelítések között abban mutatkozik hasonlatosság, hogy a munkaerő-piaci helyzet, a foglalkozás szerint pozícionálja a társadalom tagjait, és a szegénységet e struktu- 
rális viszonyok következményének tekintik, mely a jövedelem alacsony szintjében mutatkozik meg. A modern társadalom fejlődésével azonban egyre differenciáltabbá vált a kép, és minél pontosabb mérésekre törekedtek a társadalomkutatók, annál több megmérendő dimenzió bevonása vált szükségessé. Ez maga után vonta a társadalmi struktúra többdimenziós megközelítését, mely két szempontból is fontosnak mutatkozik. Egyrészt, az eddigi értelmezésekkel ellentétben, a jövedelmi helyzetet már nem következményként értékeli, hanem strukturáló tényezőként. A másik fontos szempont, hogy e megközelítés hívta életre Towsend deprivációs elméletét, mely szerint az életkörülményekben jelentkezö hátrányok halmozódása egyben az átlagtól való leszakadást is jelenti, ami nálunk a hátrányos helyzet, halmozottan hátrányos helyzet fogalmaként vált ismertté (Spéder 2002).

A szegénység klasszikus elméleti megközelítései mellett, az 1980-as években megjelenő új paradigmákat Spéder (2002) a szegénység időbeli értelmezésének tekinti, melyeket a szerint csoportosít, hogy a teória inkább a társadalmon belüli éles határokat, töréseket, vagy a társadalmi csoportok közötti átjárhatóságokat, átmeneteket hangsúlyozza inkább. A törésvonalak fontosságát hangsúlyozó elméletek közül kettőt emel ki. Az inkább európai (német) társadalomtudományban vitát indító „kétharmados társadalom” modelljét, melyet Natter, Riedlsperger, és Glotz neve fémjelez, valamint az „underclass” elméletet, mely diskurzus az USA-ban indult el, és a szerző, többek között, Auletta, Murray és Wilson nevéhez füz (Spéder 2002).

A „kétharmados társadalom” lényege, hogy a társadalom többsége kizárja a társadalom kisebb részét, hogy ezzel relatív jólétét biztosítsa. Ez leginkább a munkaerö-piaci státuszban jelenik meg, vagyis a törésvonal a tartósan munkanélküliekre, és munkával rendelkezőkre osztja a társadalmat, ami végül is a kétharmad jómódú többség, és egyharmad kiszorulók táborát jelenti, mely tartós és egyre mélyülő helyzetté válik. A szerző szerint, az „underclass” elméletet vallók többsége nemcsak egy kategóriába sorolja a halmozottan hátrányos helyzetü társadalmi csoportokat, hanem egyenesen osztályként vizsgálják. Mégpedig olyanként, melyek ,minden más osztály és réteg alatt helyezkednek el”(Spéder 2002: 30). Az említett angolszász „underclass” Európában más megnevezéssel, de azonos jelentéskörrel rendelkezik: „exclusion”, mely mára az Európai Unióban politikai programmá is vált. Mindkét elméletről úgy vélekedik a szerző, hogy újszerü gondolatrendszerük mellett, a klasszikus megközelítésektől sem esnek távol (Spéder 2002). Ha mindezt elfogadjuk, akkor nem nehéz belátni a depriváció, az „underclass”, és az „exclusion” kifejezések mögött rejlö azonos gondolatrendszert. A hátrányok halmozódása, a többségtől való leszakadást vonja maga után, mely végül is a társadalomból való kiszorulást, kirekesztődést jelenti. Ez egy olyan folyamat, mely több differenciáló tényezö mentén megy 
végbe, idővel állandósul, elmélyül, így képezve tartós és jelentős törésvonalat a társadalomban.

Visszatérve Spéder (2002) munkájához, a szegények és nem szegények közötti határvonalak megítélésében lényegesen eltérnek azok az elméleti alapvetések, melyek a társadalmi csoportok közötti átjárhatóságokat, átmeneteket hangsúlyozzák. Ulrich Beck olyan „,kockázati társadalmat” vázol fel, melyben a szegénységi kockázatok viselői nem az egyes társadalmi csoportok, hanem az egyén, aki élete során többször válhat szegénnyé, és léphet ki belőle. Az egyéni életútban a ciklikus mozgás meghatározója a foglalkoztatás, függetlenül más társadalmi státuszoktól, mint például az iskolai végzettség. Vagyis a hagyományosnak vehető rétegismérvek határai fellazulnak, átalakulnak (Spéder 2002).

Fenti áttekintésből két dilemma látszik kibontakozni, a szegénység mérésére vonatkozóan. A jövedelmi helyzet versus életkörülmények, illetve átmeneti szegények versus tartós szegények. Hasonló probléma merült fel bennem, amikor a depriváció vizsgálata mellett döntöttem. Az a kérdés foglalkoztatott, hogy a jövedelmi szegénység mögött milyen életkörülmények, ezen belül milyen felhalmozódott megfosztottságok húzódnak meg. Legelőször arra kellett megkeresnem a választ, hogy az anyagi depriváció keresztmetszeti vizsgálatából nyert pillanatfelvétel alkalmas-e kutatási kérdésem megválaszolására. Spéder Zsolt (2002) könyve ebben is útmutatásul szolgált, mindamellett, hogy a téma számtalan hazai társadalomtudóst foglalkoztat, akik közül, a teljesség igénye nélkül, említendő meg Ferge Zsuzsa (FERGE 2005), és Havasi Éva (HAVASI 2002). Visszatérve Spéder (2002) munkájához, empirikus tapasztalataira alapozva azt mondja, hogy a szegénység megismeréséhez célszerü párhuzamos megközelítéseket választani, vagyis a jövedelem mellé a fogyasztás, és életkörülmények vizsgálatát célszerű beemelni, annak figyelembevételével, hogy a depriváció időben késleltetve jelenik meg, hiszen a jövedelmi szegénység tartóssá válását feltételezzük mögötte (itt most eltekintünk a depriváció, jövedelemhiánytól eltérő okaitól). Továbbá, a szerző által keresztmetszetinek nevezett, az adatfelvétel pillanatában szegénynek számítók és a tartós szegények (longitudinális vizsgálat szerinti szegények) között nagyon sok hasonlóság mutatható ki a szegénységkockázatok tekintetében, míg az átmeneti szegénységet leginkább a társadalom mikro- mezo- és a makroszintủ változásai alakítják (Spéder 2002). E megállapításokból kiindulva tettem kísérletet a jövedelmi helyzethez közelebb álló anyagi depriváció, mint a halmozott és tartós megfosztottságokból származó, a kirekesztettség kockázatát jelentő szegénység megismerésére Nyíregyháza városának vizsgálatával.

A szegénységet és deprivációt mérő kutatásokból, az Eurostat EU-SILC (Statistics on Income and Living Conditions - Jövedelem és Életminőség Statisztika) vizsgálatát, és a hazai TÁRKI HM (Háztartás Monitor) kutatási sorozatot említeném. Az EU-SILC keresztmetszeti és longitudinális vizsgálatai 2003. 
óta biztosítanak statisztikai adatokat az Európai Unióra és tagországaira vonatkozóan. Egységes indikátor rendszerébe, az Európa 2020 Stratégia indulásakor emelték be az anyagi depriváció mérésére szolgáló, kilenc szempontú elemi indikátorsort, és a depriváció, valamint a súlyos anyagi depriváció definíciós meghatározását. Ekkortól, a kirekesztés kockázatát is számolják, a jövedelmi szegénység, a súlyos anyagi depriváció és a foglalkozás intenzitása dimenzióiból (Guio 2009, Európai Bizottság 2010, Fusco - Guio - Marler 2010). Magyarországon a TÁRKI HM vizsgálatsorozat követi nyomon a magyar háztartások életkörülményeit. A Monitorjelentésekben rendszeressé vált a relatív jövedelemi helyzetek közreadása, de a depriváció is helyet kapott a kutatásokban. Itt Havasi Éva $(2006 ; 2008)$ két vizsgálatát említeném, melynek jelentősége a depriváció mérésének módszertanában rejlik. Illetve, beemelésre kerül a legfrissebb adatokkal szolgáló tanulmány, melyet Gábos András, Szívós Péter, és Tátrai Annamária (2013) készített, és a depriváció mérésében az európai uniós definíciókra és változókra épít.

\section{A vizsgálat körülményei, kutatási eredmények}

A Nyíregyháza város életminősége - háztartáspanel kutatási sorozatában már megszokottá vált a jövedelmi szegénység vizsgálata az egyes hullámok alkalmával (Fábián - Takács 2012, Fábián - Takács - Szigeti jelen kötetben). Ez a módszer kiválóan alkalmas ugyan, a mérés pillanatában létező jövedelem eloszlások és az ebből származó egyenlötlenségek ábrázolására, de ennek tartósságáról nem árul el semmit. Továbbá, az eddigi három hullámhoz kapcsolódó munkám során azzal szembesültem, hogy a rendelkezésre álló források felöli szegénységmegközelítés mellett, érdemes és talán szükséges a fogyasztás, valamint az általa megjelenő anyagi javak oldaláról is megismerni a városban lakók életkörülményeit (Szilicsány 2009; 2013). Jelen tanulmány éppen erre ad lehetőséget. Az anyagi depriváció elemi és összetett indikátorainak segítségével arra keresem a választ, hogy milyen megfosztottságok vannak jelen 2012-ben a nyíregyházi népesség körében, ezek hogyan halmozódnak deprivációvá, és a kirekesztődés kockázati tényezőjét jelentő súlyos anyagi deprivációvá. Valószínű, hogy a város helyzete kedvezőtlenebb, ezért fontos lehet az is, hogy a mérési adatok mennyiben mutatnak eltérő képet a magyarországi helyzethez képest, ami egyébként nagyságrendekkel elmarad az Európai Unió átlagától. Említésre méltó továbbá, hogy az anyagi depriváció nem csupán a fogyasztási potenciálok hiányát ábrázolja, hanem ezen keresztül, a szegénység tartóssá válására, állandósulására is következtetni enged, ami mindenképpen hasznos információval szolgálhat, hi- 
szen a háztartáspanel eddigi három hulláma csupán a longitudinális vizsgálatok megalapozására elegendő.

\section{Definíciók és változók}

A deprivációs változók meghatározásánál elsődleges szempont volt, hogy általuk összehasonlíthatóvá váljanak a kutatási eredmények. Ezért az európai uniós meghatározásokat követtem munkám során, az anyagi deprivációt meghatározó elemi és összetett indikátorok tekintetében egyaránt, mely utóbbi, magát a fogalmat is lefedi, mint látni fogjuk. Az elemi indikátorok két csoportba sorolhatók aszerint, hogy a pénzügyi nehézségekre, illetve az anyagi javakkal való rendelkezésre irányulnak-e. Ez egy kilenc tételből álló szempontsort takar előfordult lakhatással kapcsolatos hátralék, nem engedhetik meg maguknak a lakás rendes fütését, váratlan kiadás fedezését, húsfogyasztást kétnaponta (ide értve a halat, vagy a hússal egyenértékü fehérjét), egy hét nyaralást az otthontól távol; anyagi okok miatt nincs színes TV, mosógép, autó, telefon és/vagy mobil (Fusco - Guio - Marler 2010). A kilenc változó halmozódásának számától függően két összetett indikátor került meghatározásra, melyeket deprivációs indexnek tekinthetünk, és az alábbi fogalmakat határozzák meg. Anyagi depriváció: a legalább három elemi indikátor szerinti megfosztottság. Súlyos anyagi depriváció: a legalább négy elemi indikátor szerinti megfosztottság (Fusco - Guio - Marler 2010).

Az eddigiekből következik, hogy a változó akkor kerül deprivációként értékelésre, ha a hiánynak anyagi oka van, vagyis ha a hiány kényszerü képtelenségből fakad, figyelmen kívül hagyva az egyéb okokból adódóakat. Az elemi indikátorok többsége közvetlenül kinyerhető volt az adatbázisból, két kivétellel. Összevont változók létrehozására volt szükség a telefon hiányának, illetve a lakhatással kapcsolatos hátralék előfordulásának vizsgálata esetében. Az előbbinél a vezetékes és a mobil telefon hiányának összevonása és/vagy logika szerint történt. E logikát követve, de többszörös összevonással állt elő a lakhatással kapcsolatos hátralék előfordulását vizsgáló tétel, mely esetben, lakhatással kapcsolatosnak tekintendő a lakbér, lakás törlesztő részlete, közös költség, közüzemi díj, illetve a lakhatást közvetve befolyásoló fogyasztási hitel és pénz kölcsön megfizetésében előforduló hátralék.

A különböző demográfiai és társadalmi jellemzők mentén történő elemzéssel kapcsolatban két körülményt kell rögzítni. Az egyik, a jövedelmi szegénység definiálása, mely szerint jövedelmi szegénynek tekintettem a relatív, medián, ekvivalens jövedelem 60\%-nál kevesebb jövedelemmel rendelkező háztartásban élőket, az OECD2 ekvivalencia skála alkalmazása mellett. A másik körülmény inkább problémaként merült fel. Az életkori csoportok szerinti bontása nehézségekben ütközött, miután erre vonatkozóan, a háztartásfőkkel kapcsolatos adatok álltak rendelkezésre az adatbázisban. A 0-17 éves korosztály esetében lehetőség kínálkozott ugyan a családszerkezet változóiból való adatvisszanyerésre, de ez 
szétfeszítette volna jelen tanulmány időkereteit. A 18-24 éves korosztály teljes körü meghatározásához ez a lehetőség sem volt adott, ezért csupán azok kerülhettek be a vizsgálat körébe, akik e korosztály tagjaként már családfök voltak.

\section{Az anyagi depriváció előfordulásának és megoszlásának arányai}

A nélkülözésben élők megismeréséhez elsőként érdemes azt vizsgálnunk, hogy a kilenc elemi indikátor szerint, milyen deprivációs tényezők vannak jelen, és arányai miképpen alakulnak a mért nyíregyházi népesség körében. Ez nemcsak az elszenvedett hiányok mértékét mutatja meg, hanem egyúttal tekinthetjük a jólét minőségi tényezőjének is. Mindezekről az 1. számú ábrán látható adatok árulkodnak számunkra.

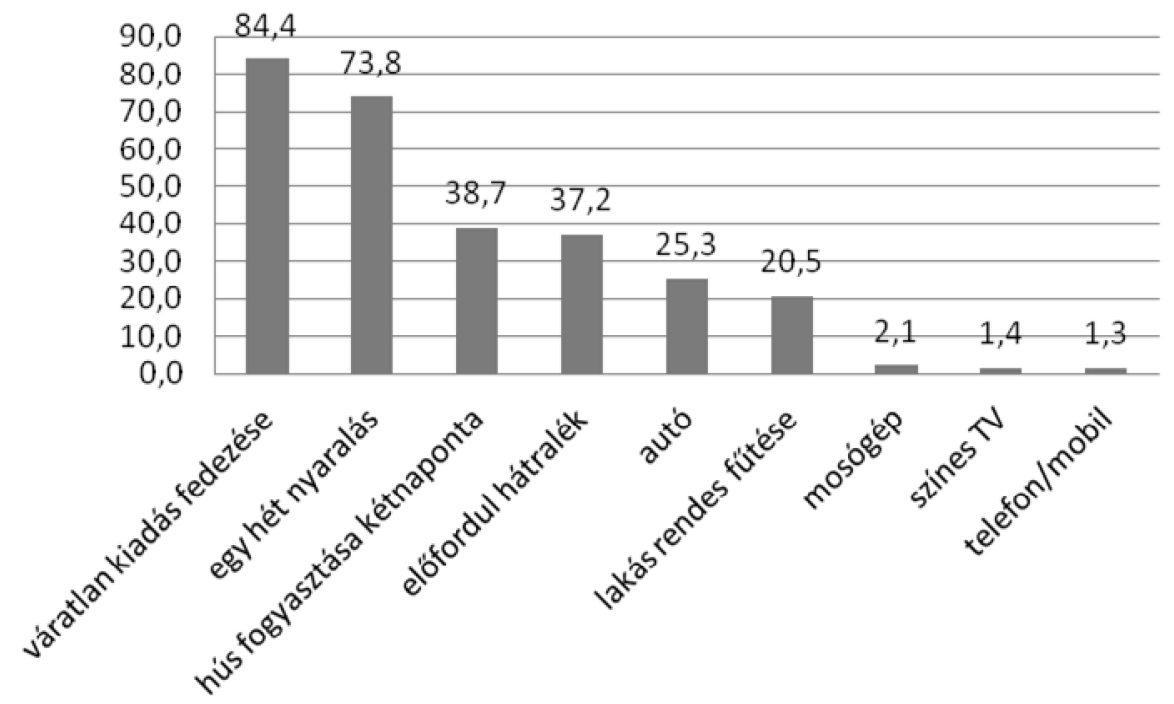

1. ábra. Az anyagi depriváció elemi indikátorok szerinti megoszlása (\%).

Forrás: saját számítások, 2012.

A fenti százalékos megoszlásokból a hiányok és nélkülözések három, jól körülhatárolható csoportja rajzolódik ki. A nyíregyházi lakosság döntő többségét érinti, hogy nem engedheti meg magának váratlan kiadás fedezését $(84,4 \%)$, illetve évente egy hét nyaralást az otthonán kívül $(73,8 \%)$. Bár e két tényező inkább tekinthető közép-, esetleg hosszútávon jelentkező életminőség romlásnak, mégis súlyos kockázatokat takarhatnak. Gondoljunk csak egy hosszabb gyógykezelést kívánó betegség váratlan fellépésére, de ilyen eset lehet a munka elvesztésével, és az új munka keresésével fellépő költségek. A szinte „luxusnak” tünő nyaralás kényszerü elmaradása pedig csökkenti a szellemi és fizikai teherbírást, ami kihat 
az egyén életesélyeire, munkaerőpiaci helyzetére, végső soron jövedelmi helyzetére és fogyasztási potenciáljára.

A második csoportba azokat az elemi indikátorok sorolhatóak, melyek a lakosság jelentős részét sújtják. 38,7\% nem engedheti meg magának hús fogyasztását kétnaponta (ide értve a halat, és a hússal egyenértékü fehérjét is); 37,2\%ban fordul elő hátralék, mely kapcsolatos a lakhatással, valamint a mért népesség 25,3\%-a anyagi okok miatt nem rendelkezik autóval, és 20,5\%-nak okoz gondot a lakás rendes fütése. Ha áttekintjük ezeket a deprivációs tényezőket, jól látható, hogy átlagosan, a mért népesség 30\%-nak, azaz csaknem egyharmadának nehézségekbe ütközik a létfenntartáshoz szükséges dolgok, mint a lakhatás és élelem biztosítása. Ez két okból is jelzésértékü lehet. Egyfelől, ezeknek a háztartásoknak a kockázata a súlyos anyagi deprivációra, és a társadalmi kirekesztődésre, feltételezhetően igen magas. Másfelől, a „,kétharmados társadalom” elméleti modelljét látszik alátámasztani, mely szerint a társadalom kétharmada, saját jólétének biztosítása érdekében, feláldozza, sőt kizárja magából az egyharmadot. Erre utaló jelekkel még találkozni fogunk a tanulmány egy további részében, mely a deprivációk halmozódását taglalja.

Első ránézésre, az autó hiányát „kakukktojásnak” vélhetjük a fenti elrendeződésben, hiszen tartós fogyasztási eszközként nem sorolható a pénzügyi nehézségek közzé. Mégis találhatunk kapcsolatot a létszükségletekkel, mert gyorsan változó világunkban nem csupán a mindennapi életünk szervezésében és lebonyolításában játszhat szerepet, hanem egyre inkább szükségessé válik munkavégzésünkhöz is, így közvetve a létfenntartás egyre inkább elengedhetetlen részévé válik Ebből a szempontból nézve, a nyíregyháziak több mint egynegyedét érintő hiányt jelentősnek tekinthetjük. Annál is inkább, mert ennek a fajta deprivációnak a mértéke csak lassan változik, hiszen nagyobb anyagi befektetést igénylő eszközről van szó. Ugyanez mondható el a harmadik csoport tényezőiről is. Ilyen a mosógép $(2,1 \%)$, a színes TV $(1,4 \%)$, vagy a telefon/mobil $(1,3 \%)$ anyagi okokra visszavezethetö nélkülözése. Bár ezekkel a tartós fogyasztási cikkekkel a lakosság túlnyomó többsége rendelkezik, a mért arányok arra utalnak, hogy feltehetően, a mélyszegénységben és/vagy súlyos deprivációban élök háztartásában tartósan nincsenek jelen, hiszen megszerzésükhöz hosszútávon kellene megfelelő jövedelemi színvonalat elérni.

Az eddigi adatokból arra következtethetünk, hogy a nyíregyházi lakosság mintegy harmadában fordultak elö mindennapi anyagi gondok a fizikai szükségletek kielégítése terén, és jelentős többségük olyan háztartásban él, mely nem rendelkezik nehéz helyzetben mobilizálható jövedelmi tartalékkal.

Az anyagi javaktól való megfosztottság kilenc elemi indikátorának kiterjedtsége azonban nem mond számunkra semmit arról, hogy a depriváció miképpen halmozódik, és hogyan osztja fel a várost a mainstream társadalomra (ami a fentiek ismeretében nem biztos, hogy egyben a többséget is jelentené), és a nél- 
külözésben, kirekesztettség kockázatában élőkre. Erre vonatkozóan az alábbi táblázatban foglalt adatok nyújtanak információkat.

\begin{tabular}{|l|c|}
\hline Deprivációtól mentes & 7,0 \\
\hline 1 elemi indikátor szerinti depriváció & 14,3 \\
\hline 2 elemi indikátor szerinti depriváció & 25,0 \\
\hline 3 elemi indikátor szerinti depriváció & 20,6 \\
\hline 4 elemi indikátor szerinti depriváció & 18,3 \\
\hline 5 elemi indikátor szerinti depriváció & 9,3 \\
\hline 6 elemi indikátor szerinti depriváció & 4,7 \\
\hline 7 elemi indikátor szerinti depriváció & 0,7 \\
\hline 8 elemi indikátor szerinti depriváció & 0,1 \\
\hline 9 elemi indikátor szerinti depriváció & 0,0 \\
\hline Összesen: & $\mathbf{1 0 0 , 0}$ \\
\hline Nem számít depriváltnak & 46,3 \\
\hline Legalább 3 elemi indikátor szerint deprivált & 53,7 \\
\hline Legalább 4 elemi indikátor szerint deprivált & 33,1 \\
\hline
\end{tabular}

1. táblázat. Az anyagi depriváció halmozódása (\%).

Forrás: saját számítások, 2012.

Az 1. táblázat gyakorisági eloszlását áttekintve, a következőket láthatjuk. Az anyagi nélkülözés halmozódása, a depriváció nélkül élők és a két szempontból nélkülözők intervalluma között egy eröteljes növekedési tendenciát mutat. Az anyagi nehézségektől mentes populáció $7 \%$-os aránya a deprivációs tételek emelkedésével egyenes arányban, szinte megduplázódik, hiszen az egy szempont szerint depriváltak már 14,3\%-os arányt képviselnek, a két szempont szerintiek pedig 25\%-ot. Ez az aránynövekedési ütem megtorpan, sőt enyhe csökkenést mutat a háromszoros és négyszeres deprivációknál. Az előbbi 20,6\%, míg az utóbbi 18,3\%. A 4-6 elemi indikátor szerinti deprivációk jelenlétét ábrázoló intervallumban azonban újra eröteljesebb tendencia tapasztalható, de fordított arányban. Vagyis a nélkülözési szempontok növekedésével, az azt elviselni kényszerülők aránya csökken, mégpedig majdnem pontosan feleződik 18,3\%-ről 9,3\%-ra, majd 4,7\%-ra. Végül a halmozódási folyamat jelentősen lelassul, és a szélsőségesen súlyos anyagi depriváció aránya $1 \%$ alá süllyed a hét elemi indikátor $(0,7 \%)$, és a nyolc elemi indikátor $(0,1 \%)$ együttes jelenléte esetében, illetve, a kilenc indikátor szerinti depriváció már jelen sincs. 
Bár a szélsőségesen rossz helyzetekben élők száma csekély, ezt a képet lerontja, hogy az ellentétes póluson lévő jó helyzetüek aránya csupán 7\%-nyi. Ezt inkább tekinthetjük szélsőségesen rossz helyzetnek, sőt tragikusnak, hiszen azt jelzi, hogy az alapvető jólét, az elvárható minimális anyagi és pénzügyi biztonság, nagy valószínüséggel a legfelső jövedelmi tizedbe tartozók kiváltsága lehet Nyíregyháza népességét tekintve. Ha megfigyeljük, hogy akkor a mért népesség többsége mely halmozódási tényezők körül helyezkedik el, azt láthatjuk, hogy a két, három, és négy elemi indikátor együttes jelenléte mentén tömörül, 63,9\%-os összesített arányban, tehát az anyagi deprivációban jelentősen érintettek. Összegezve, az adatok és a depriváció halmozódásának folyamata kedvezőtlen képet mutat. Az életkörülmények pontosabb megismeréséhez itt emelném be az Európai Unió meghatározását, mely szerint deprivált az, aki legalább három elemi indikátor szerint hiányt szenved, és súlyosan deprivált az, aki legalább négy elemi indikátor mentén nélkülöz. Ebből kiindulva, nem számít depriváltnak, aki deprivációmentes, és akinél egy vagy két deprivációs tényező fordult elő a megfigyelési időszakban. Mindezek alapján, az 1. táblázatban szereplő elemi indikátorok összevonását követően, a depriváció az alábbiak szerint alakul a városban:

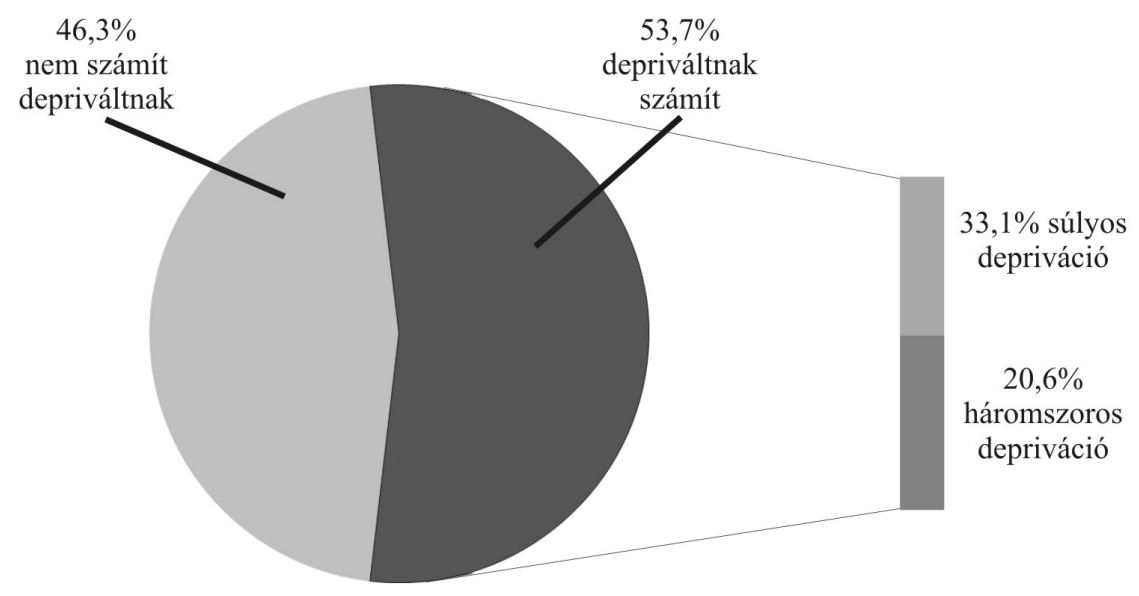

2. ábra. Az anyagi depriváció jelenléte Nyíregyházán (\%).

Forrás: Saját számítás, 2012.

A korábbi feltételezést, miszerint a depriváció jelentős mértékben jelen van a nyíregyházi háztartások körében, megerősíti, és pontosítja számunkra a fenti 2. ábra. Mint látható, a 46,3\%-os fóáram, melynek a helyi társadalomban a normálisnak tekinthető, a többség által elfogadott életkörülményekkel kellene rendel- 
keznie, nincs többségben, még akkor sem, ha a mérés néhány százalékos hibalehetőségét figyelembe vesszük. Sőt, ha visszaemlékezünk az elemi indikátorok szerinti kétszeres halmozódás 25,0\%-os mértékére, akkor más kedvezőtlen tényező is említhető. Ugyanis, a depriváltnak nem számítók halmazán belüli elhelyezkedésük mellett, egyben a deprivációhoz közeli életkörülményekkel rendelkezőket is jelentik, és mértékük a lakosság egynegyedét teszi ki.

További aggasztó adat a depriváltak 53,7\%-os nagysága. Nemcsak azért, mert ez valamivel több, mint a lakosság felét jelenti. Nézzük meg a 2 . ábra szerinti megbontást: a „csak” depriváltnak számítók 20,6\%-ot tesznek ki, ami a mért népesség egyötödét jelenti. Ök képezik Nyíregyháza társadalmának azon részét, akik határmezsgyét alkotnak a nélkülözők, és a társadalmilag elfogadott életkörülményekkel rendelkezők között. Valószínüleg egyetlen váratlanul fellépő rendkívüli élethelyzet, vagy gazdasági, politikai változás, egyben elmozdulást is jelent a számukra fölfelé, vagy lefelé, a változás irányától függően. Feltételezhetö, hogy többségükben a szegénységből ki- vagy belépőkröl lehet szó, így leginkább az átmenetileg szegények meghatározásához állnak közelebb, (az irracionális fogyasztás, esetleg egyéb tényezők közrejátszása folytán labilis helyzetủeket most figyelmen kívül hagyva). Talán érdeklődésre adhat számot, egy további kutatás témájaként, ennek a feltevésnek az ellenőrzése. A megfosztottságban élők többsége viszont, még ettől is rosszabb helyzetben van. A nyíregyháziak 33,1\%-a sorolható a súlyosan depriváltak közé, vagyis a városnak több mint egyharmada halmozottan hátrányos helyzetü, és a társadalmi kirekesztettség kockázatát viseli. Ez ismét felveti a kétharmados társadalom jelenlétének lehetőségét, még akkor is, ha Nyíregyháza földrajzi helyzete, mint tudjuk, kedvezötlen.

Összességében azt tapasztalhatjuk, hogy a városban élők nagyobb hányada anyagi szempontból deprivált, és ezen belül az érintettek többsége súlyosnak számító megfosztottságot szenved el. A lakosság körében elfoglalt 33,1\%-os arányuk aggodalomra ad okot. A kedvezőtlen helyzetet tovább súlyosbítja a deprivációmentesnek számító népesség megoszlása, hiszen az egy és két anyagi probléma, többségüknél már jelen van, teljesen problémamentesen csupán 7\% él.

\section{Nyíregyháza relatív helyzete}

Ez idáig arra kerestük a választ, hogy a depriváció elemi és összetett indikátorai mentén, az anyagi javaktól való megfosztottság egyes dimenziói milyen mértékben vannak jelen, és halmozódásuk hogyan osztja fel a helyi társadalmat. Miután jelen tanulmány a relatív helyzetek vizsgálatára irányul, felmerül a kérdés, hogy a nyíregyházi életkörülmények milyen mértékben azonosak, vagy térnek el a magyar társadalom helyzetétől, és az Európai Unió átlagától. Az összehasonlításhoz megjelenítésre kerülnek a TÁRKI Háztartás Monitor 2012. évi kutatási eredményei (Gábos, Szívós, Tátrai 2013), valamint az Eurostat EU-SILC 2012. 
évben közölt magyarországi adatai. Az Európai Unió átlagainak tekintettében viszont, a 2011. évre vonatkozó statisztikákat alkalmaztuk, az EU27 vonatkozásában, miután a legfrissebb adatok közzététele az Eurostat részéröl nem történt meg jelen tanulmány (2013 nyara) megírása ideje alatt (Internet1).

Mielőtt a számok boncolgatásához fognánk, egy fontos tényt még szükséges rögzíteni, ami a további elemzés csomópontjait, és menetét is kijelölte. Az Eurostat statisztikája szerint, a súlyos anyagi depriváció mértéke az EU27 átlagában, 8,8\%, Magyarországon 23,1\% volt 2011. évi adatközlés szerint (Internet2). Azonban a magyar társadalomra vonatkozó adat nem csak az európai átlaghoz képest magas, hanem az európai uniós országok többségéhez is. A 27 tagállam rangsorában igencsak hátul kullogva, csupán Romániát $(29,4 \%)$, Lettországot $(31,4 \%)$, és Bulgáriát $(43,6 \%)$ előzzük meg (Internet2). A minden tekintetben rossz helyzet ismeretében, indokoltnak látszott a kiterjedtségek elemzésénél, egy-két kivétellel, csupán a tendenciákra fókuszálni.

A fentiek figyelembevételével, a továbbiakban először az anyagi depriváció elemi és összetett indikátorai szerint megjelenő hiányok kiterjedtségével foglalkozunk, a már ismert kilenc szempontot, illetve a depriváció és súlyos anyagi depriváció meghatározását követve. Majd néhány demográfiai és társadalmi jellemző mentén vizsgálódunk, mint nem, életkor, iskolai végzettség, jövedelem, melyek a szegénység kockázati tényezőiként számon tartott ismérvek.

Az elemi és összetett indikátorok adatsorait kibővítve, a 2. táblázatban, mintegy összefoglalva válik láthatóvá az anyagi depriváció kiterjedtségének alakulása az Európai Unióban, Magyarországon, és Nyíregyházán.

Ami legelőször szembeötlőnek látszik a 2. sz. táblázat adatközlőinél, hogy az egyes elemi indikátorok arányainak nagyságrendjéből kirajzolódó deprivációs csoportok megegyeznek, a Nyíregyházi adatok elemzésekor körvonalazódott probléma-csoportokéval. Az Európai Unió tagállamaiban, a Magyarországon és Nyíregyházán élőkre egyaránt jellemző, hogy elsősorban pénzügyi nehézségekkel küzdenek. Ezen belül is nagyobbak a tartalékképzési gondok, ami a váratlan kiadás fedezésének képtelenségében $(37,7 \% ; 74,3 \% ; 80,9 \% ; 84,4 \%)$, és az egy hetes nyaralás elmaradásában $(36,8 \% ; 67,0 \% ; 77,1 \% ; 73,8 \%)$ mutatkozik meg. Kisebb kiterjedtséget mutat, de még mindig jelentősnek mondható, az alapvető fizikai szükségletekben megjelenő nélkülözés, mint a lakhatással összefüggő hátralékok jelenléte $(11,5 \% ; 26,4 \% ; 24,3 \% ; 37,2 \%)$, a lakás nem megfelelő fütése $(9,8 \% ; 14,5 \% ; 27,4 \% ; 20,5 \%)$. Továbbá, a megfelelő táplálkozás $(9,6 \%$; $32,0 \% ; 44,7 \% ; 38,7 \%$ ) hiánya is. A tartós fogyasztási cikkek vonatkozásában is hasonló helyzetkép látszik. Az autó kivételével $(8,3 \% ; 22,6 \% ; 28,6 \% ; 25,3 \%)$, minden más tárgy esetében $10 \%$ alatti a kiterjedtség aránya. 


\begin{tabular}{|c|c|c|c|c|}
\hline & \multicolumn{2}{|c|}{ EUROSTAT } & \multirow{2}{*}{\begin{tabular}{|c|} 
TÁRKI \\
MAGYARO. \\
\end{tabular}} & \multirow{2}{*}{\begin{tabular}{|c|} 
PANEL III. \\
NYÍREGYH.
\end{tabular}} \\
\hline & EU27* & HU** & & \\
\hline \multicolumn{5}{|c|}{ Az anyagi depriváció elemi indikátorai } \\
\hline Lakhatással kapcsolatos hátralékok & 11,5 & 26,4 & 24,3 & 37,2 \\
\hline \multicolumn{5}{|l|}{ Nem engedheti meg magának: } \\
\hline a lakás rendes fütését & 9,8 & 14,5 & 27,4 & 20,5 \\
\hline váratlan kiadás fedezését & 37,7 & 74,3 & 80,9 & 84,4 \\
\hline hús/hal fogyasztását kétnaponta & 9,6 & 32,0 & 44,7 & 38,7 \\
\hline az egy heti nyaralást & 36,8 & 67,0 & 77,1 & 73,8 \\
\hline \multicolumn{5}{|l|}{ Anyagi okokból nincs: } \\
\hline színes TV & 0,4 & 0,4 & 0,4 & 1,4 \\
\hline mosógép & 1,3 & 0,6 & 7,5 & 2,1 \\
\hline autó & 8,3 & 22,6 & 28,6 & 25,3 \\
\hline telefon & 0,7 & 1,6 & 3,5 & 1,3 \\
\hline \multicolumn{5}{|c|}{ Az anyagi depriváció összetett indikátorai } \\
\hline Egyetlen indikátor szerint sem deprivált & 49,7 & 16,2 & 9,7 & 7,0 \\
\hline Anyagi depriváció & 18,2 & 44,0 & 56,1 & 53,7 \\
\hline Súlyos anyagi depriváció & 8,8 & 25,7 & 37,3 & 33,1 \\
\hline
\end{tabular}

2. táblázat. Az anyagi depriváció kiterjedtségének EU-s és hazai viszonylatai (\%). Forrás: Eurostat EU-SILC, *2011; **2012; Tárki Háztartás Monitor, 2012; Saját számítások, 2012.

Eltérés mutatkozik viszont a gyakorisági eloszlás két szélsőértékében, ami egyben kihat az anyagi depriváció halmozódásának összképére is. Míg az EU27-ben átlagosan a népesség 49,7\%-át nem érinti egyáltalán a deprivácó, addig ez hazánkban az Eurostat közlésében 16,2\%, a TÁRKI mérése szerint 9,7\%, és Nyíregyházán 7,0\%. A szélsőségesen rossz helyzeteknél ezek az arányok szinte megfordulnak. A súlyos anyagi depriváció jelenléte az Európai Unió átlagában 8,8\%, (EU27) hazánkban 25,7\% (HU) (Eurostat), 37,3\% (TÁRKI), illetve Nyíregyháza esetében 33,1\% (PANEL III.). Míg az uniós polgárok jelentős része él a kirekesztés kockázata nélkül, és egyúttal a súlyos anyagi depriváció is alacsony szinten jelenik meg, addig Magyarországot és Nyíregyházát az jellemzi, hogy a lakosság egyharmad körüli arányát érinti a tartósabb nélkülözés, és a jólét csak kevesek kiváltsága. 
Az ország és Nyíregyháza viszonylatában is látszik némi eltérés. Azt láthatjuk, hogy az Eurostat által közölt magyar adatok mintegy 10 százalékponttal mutatnak kedvezőbb képet, mint a TÁRKI, illetve a saját mérési eredmények, mely két utóbbi viszont közelít egymáshoz, tendenciájában, és az arányok nagyságában is. Az viszont mindenképpen feltételezhető, hogy a Nyíregyházán élők, területi helyzetükből fakadóan, valamivel kedvezőtlenebb helyzetben vannak, mint a magyarországi átlagpolgárok. Eddig azt láthattuk, hogy Magyarország, és benne a város hol helyezkedik el az európai közösségben. Azt is feltételezhetjük, hogy az anyagi javak megléte, vagy kisebb-nagyobb hiánya miképpen alakul, és mértéke szerint hogyan osztja fel az egyes közösségeket szegényekre és nem szegényekre. De még nem ismerhettük meg, hogy kik lehetnek ők. Ehhez, a leggyakrabban használt demográfiai és társadalmi jellemzők szerinti - nem, életkor, iskolai végzettség és a jövedelem - kiterjedtségeket használjuk. Elöljáróban két körülményt szükséges rögzíteni. Egyrészt, a definíciók és változók címü fejezetben tisztázásra került a korcsoporti bontásokkal kapcsolatos nehézségek, mely némi adattorzítást eredményez. Másrészt, a jövedelmi helyzet meghatározásánál szegénynek tekintendők a relatív, medián, ekvivalens jövedelem 60\%-nál kevesebb jövedelemmel rendelkező háztartásban élők.

Fentiek figyelembevételével, tekintsük át a 3. táblázatban összefoglalt adatokat, melyek egyúttal betekintést engednek a szegénység sokféleségébe, megjelenési formáiba is.

A felületes szemlélő számára is világosan látszik, hogy az egyes jellemzők tendenciái többségében azonos irányba mutatnak mindegyik adatközlő esetében. Kivételt képez a jövedelmi kiterjedtségek alakulása. De nézzük részletesebben, hogy kikre jellemzőbb az anyagi javaktól való megfosztottság: inkább a nőkre, a gyermekekre és fiatal felnőttekre, illetve az alacsony iskolai végzettséggel rendelkezőkre. A számok jól ábrázolják, hogy az életkor előrehaladtával, illetve az egyre magasabb iskolai végzettség megszerzésével a szegénység és kirekesztettség kockázatai csökkennek. Nem nehéz észrevenni, hogy a súlyos anyagi megfosztottság kockázati tényezőiből előálló tendenciák megegyeznek, az egyébként, a jövedelmi szegénység kockázatára jellemző tendenciákkal (Tóth 2006, Gábos-Szívós-Tátrai 2013). 


\begin{tabular}{|c|c|c|c|c|}
\hline & \multicolumn{2}{|c|}{ EUROSTAT } & \multirow{2}{*}{$\begin{array}{c}\text { TÁRKI } \\
\text { MAGYARO. }\end{array}$} & \multirow{2}{*}{$\begin{array}{l}\text { PANEL III. } \\
\text { NYÍREGYH. }\end{array}$} \\
\hline & EU27* & HU** & & \\
\hline Teljes népesség & 8,8 & 25,7 & 37,3 & 33,1 \\
\hline \multicolumn{5}{|c|}{ Nem } \\
\hline Férfi & 8,5 & 25,2 & 36,0 & 30,4 \\
\hline Nő & 9,0 & 26,1 & 44,0 & 34,9 \\
\hline \multicolumn{5}{|c|}{ Életkor } \\
\hline $0-17$ & 10,0 & 33,4 & 44,0 & n.a. \\
\hline $18-24$ & 10,6 & 30,1 & 44,0 & 19,0 \\
\hline $25-49$ & 8,7 & 25,5 & 33,0 & 30,7 \\
\hline $50-64$ & 8,3 & 23,8 & 37,0 & 35,4 \\
\hline $65+$ & 7,2 & 17,4 & 34,0 & 36,4 \\
\hline \multicolumn{5}{|c|}{ Iskolai végzettség } \\
\hline Legfeljebb alapfokú & 13,1 & 41,6 & 63,0 & 54,8 \\
\hline Középfokú & 8,0 & 21,6 & $* * * 33,0$ & 36,4 \\
\hline Felsőfokú & 2,7 & 8,5 & 14,0 & 17,6 \\
\hline \multicolumn{5}{|c|}{ Jövedelem } \\
\hline Csak jövedelmi szegénység jelenléte & 9,8 & 3,3 & 2,8 & 4,7 \\
\hline Csak súlyos anyagi depriváció jelenléte & 4,0 & 14,6 & 18,7 & 24,6 \\
\hline $\begin{array}{l}\text { Jövedelmi szegénység és súlyos anyagi } \\
\text { depriváció együttes jelenléte }\end{array}$ & 2,6 & 4,6 & 5,9 & 9,4 \\
\hline
\end{tabular}

3. táblázat. A súlyos anyagi depriváció, néhány jellemző mentén (\%).

Forrás: Eurostat, EU-SILC *2011;**2012; TÁRKI Háztartás Monitor, 2012; ***TÁRKI HM 2012-ből saját becslés; Saját számítások, 2012.

Ha az egyes változókat tüzetesebben vizsgáljuk, akkor a kiterjedtségek arányai már nem mutatnak ilyen egységes képet. A férfiak és nők közötti különbség az EU27 esetében 0,5 százalékpont, míg a magyarországi adatoknál ez közel 1 (HU), pontosan 8 (TÁRKI), illetve Nyíregyházán több mint 4 (PANEL III.) százalékpontnyi eltérést jelent, a nők hátrányára, a 3. sz. táblázat adatai szerint. Az életkor estében, a fentebb említett nehézségek miatt, kizárólag a 25-65+ korcsoportokat vizsgálva, az egyes kategóriák közötti aránybeli különbség az EU27 esetében 0,4-1 százalékpont eltérés körül mozog, míg a hazai adatközlőnél 1,5-5 
százalékpont körül. Vagyis, minden adatközlöre vonatkoztatva, azt láthatjuk, hogy bár a demográfiai jellemzők és a szegénység között van összefüggés, de kirívóan nagy, szélsőséges kockázati tényezőt nem találhatunk.

A társadalmi jellemzőket nézve azonban, más helyzet látszik. Az iskolai végzettséggel kapcsolatban már rögzítésre került, hogy az adatközlök tendenciái hasonlóan alakulnak, vagyis a végzettség növekedésével, az anyagi depriváció csökken. A kiterjedtségek viszont jelentős eltérést mutatnak. Az iskolázottság egyes szintjei között az EU27-ben 5 százalékpont körüli eltérés van, míg a hazai adatok tekintetében ez 20, sőt megközelítheti a 30 százalékpont körüli értéket. Az összehasonlításból az látszik, hogy a magyar lakosságnak, beleérve a Nyíregyháziakat is, sokkal nagyobb a kockázata az anyagi deprivációra, az iskolai végzettségtől függetlenül, a mint az átlagos uniós polgárnak.

Ha az uniós számokat figyelmen kívül hagyjuk, és csupán a magyarországi és nyíregyházi mérési eredményeket vesszük, akkor az elemi és összetett indikátoroknál tapasztaltakat látjuk. Az Eurostat adatai valamivel alacsonyabb értéket mutatnak, a TÁRKI és a nyíregyházi adatsorokhoz képest, és e két utóbbi itt is közelíteni látszik egymáshoz. Minden eddigi szempontból eltérést mutatnak viszont, a jövedelemi adatok.

A jövedelmi helyzet tendenciái, a kiterjedtségek mértékei és egymáshoz való viszonyulásuk, sem az Európai Unió versus hazai adatok, sem a két magyarországi versus nyíregyházi adatközlések tekintetében nem mutatnak hasonlóságot. Annyit talán felfedezhetünk, hogy az eddigiektől eltérően, inkább a Magyarországra vonatkozó Eurostat, és a TÁRKI adatsorai közelítenek egymáshoz. Nézzük először az Európai Unióhoz viszonyított eltéréseket. A tendenciákra nézve, az EU27-ben azok aránya, akik a relatív medián ekvivalens jövedelem $60 \%$-a alatt élnek, azaz jövedelmi szegények, de a súlyos anyagi deprivációban nem érintettek, 9,8\%. Ez több mint kétszerese azok arányának, akiknél csak súlyos anyagi depriváció van jelen, de jövedelmük szerint nem számítanak szegénynek. Ök a népesség $4 \%$-át teszik ki, és esetlegesen a szegénységből ki- és/vagy belépőket, illetve a valamely okból nem racionális fogyasztókat takarja. A jövedelmi szegénység és súlyos anyagi depriváció együttes jelenléte pedig 2,6\% (EU27). Ök valószínüleg a tartós mélyszegénységet élik meg, és az európai uniós kockázati tényezőből kettő jelenléte azt a feltételezést is erősítheti, hogy kirekesztettek. A számok azt mutatják, hogy az átlagos népességben inkább a jövedelmi szegénység van jelen, míg a tartós megfosztottságot elszenvedök összesen $6,6 \%$ ot képviselnek, ami csupán kétharmada az előbbinek. A hazai helyzet viszont mást mutat. A számok alakulásából arra a tendenciára lehet következtetni, hogy az Európai Unióval ellentétben, nálunk inkább a tartósnak látszó szegénység jellemzőbb. Összességében ez nagyjából 19-34\% között mozog, az adatforrások különbözősége szerint, ami azért is aggasztóbb, mert így a kirekesztettség kockázata, és tartóssá válása is nagyobb mértékünek ítélhető meg. Ha a jövedelmi 
helyzetet az egyes változók mentén vizsgájuk, akkor az Eurostat, a TÁRKI, és a nyíregyházi adatok úgy alakulnak, hogy a csak jövedelmi szegények aránya a népességen belül $3,3 \% ; 2,8 \%, 4,7 \%$ az adatforrások fentebb meghatározott sorrendjében. Ugyanígy vizsgálódva, a súlyos anyagi depriváció jelenléte 14,6\%, $18,7 \%$, és $24,6 \%$, mely számok világosan mutatják, hogy a mérések idején, jövedelmük szerint szegénynek nem számítók, eléggé népes tábora nehéz életkörülmények között él. A legsúlyosabb helyzetủek, vagyis azok, akik nem csak jövedelmi szegények, de tartósabban súlyos anyagi megfosztottságokkal rendelkezők előfordulása sem mondható az európai átlaghoz közelítőnek a 4,6\%, $5,9 \%$, és a 9,4\%-os értékekkel. Mint fentebb már említettem, a Magyarországra vonatkozó mérések ebben a tekintetben közelítenek egymáshoz, és egyben ez azt is jelenti, hogy valamivel kedvezőbb képet is mutat, hiszen Nyíregyháza kiterjedtségei bizony több százalékponttal eltérnek ettől. A fentiek alapján akkor elmondható, hogy a jövedelmi és anyagi helyzet szempontjából, valószínüleg rosszabb életkörülmények fordulnak elő a városban. További kutatásra érdemes kérdés, hogy a tartósabbnak látszó súlyos anyagi depriváció, területi eloszlás szerint hogyan alakul a városban.

\section{Összegzés}

A depriváció, mint fogalom, és többdimenziós mérési módszer, nem csak a tartós szegénységet meghatározó új paradigmákkal mutat sok hasonlóságot, de alkalmas lehet, a kirekesztettségben megnyilvánuló szegénység viszonylag gyors, és pontos meghatározására is. Az Európai Unió által meghatározott deprivációs indikátorok és definíciók pedig lehetővé teszik, hogy a közösségi, tagállami, és helyi vizsgálatok eredményeit összevethessük.

A Nyíregyházán, 2012-ben készült adatfelvételből készült statisztikai számítások szerint, a kilenc elemi indikátor megoszlásai azt mutatják, hogy leginkább a pénzügyi nehézségek jellemzőek. Ezen belül is a tartalékképzésben mutatkoznak meg nagyarányú nehézségek, mint a váratlan kiadás fedezése $84,4 \%$ ), és az egy hét nyaralás elmaradása $(73,8 \%)$. Ehhez képest, a létfenntartást veszélyeztető körülmények közepes szintünek ítélhetők meg, bár a lakhatással felmerülö hátralékok, a fütetlen lakás, és a nem megfelelö táplálkozás átlagos aránya így is kedvezőtlennek mondható, hiszen a háztartások 30\%-ban van jelen. Tartós fogyasztási cikkekkel a lakosság túlnyomó többsége rendelkezik, a mért hiány 1$2 \%$-os. Ez alól kivételt képez a háztartások több mint $25 \%$-a, akik nem rendelkeznek autóval, ami modern életünk szervezésében és a munkavállalásban egyre fontosabbá válik. 
A depriváció halmozódásának gyakorisági eloszlása tekintetében, nagy sürüséget mutat a 2-3-4 tényező szerinti nélkülözés, ami összességében a mért népesség 63,9\%-át jelenti. A szélsőségesen súlyos megfosztottságok erőteljes csökkenést mutatnak az elemi indikátorok számának növekedésével, ami igen kedvező, de ezt lerontja az ellenpólus, a deprivációk nélküli jólét 7\%-os aránya, ami tragikusan alacsony. Az Európai Unió meghatározásait követve, a depriváció, az alábbiak szerint osztja fel a város társadalmát: nem számít depriváltnak a népesség 46,3\%, így értelemszerűen, 53,7\% deprivált. Ezen belül a súlyosan depriváltak aránya 33,1\%, azaz a lakosság több mint egyharmada. A számok más kedvezőtlen jelenséget is mutatnak, a társadalom által elfogadott jóléti szinttel rendelkező mainstream nincs többségben, és a leginkább átmeneti szegénynek jellemezhetőek, vagyis a „csak” háromszoros deprivációval, a határmezsgyén élők aránya (20,6\%) sem elhanyagolható.

Nyíregyháza relatív helyzetének elemzésénél elsősorban a tendenciák vizsgálatára került a hangsúly, hiszen az Európai Unió átlagához képest maga Magyarország is az utolsó helyek egyikét foglalja el a depriváció szintjét illetően. Az elemi indikátorok szerinti megoszlás a Nyíregyházival azonos tendenciát mutat, mind az Eurostat EU27-re és Magyarországra, mind a TÁRKI magyarországi adataira vonatkoztatva. Vagyis, a népesség elsősorban pénzügyi nehézségekkel küzd, ezen belül kiemelkedik a tartalék képzés problémája, de a létfenntartási gondok sem elhanyagolhatóak. Az autó kivételével, a népesség túlnyomó többsége rendelkezik az elvárható tartós fogyasztási cikkekkel. A depriváció halmozódása esetében az látszik, hogy az uniós polgárok jelentős része a kirekesztés kockázata nélkül él, a súlyos anyagi depriváció szintje alacsonynak mondható, míg Magyarországon a lakosság mintegy egyharmadát érinti a súlyos nélkülözés, és a jólét csak kevesek kiváltsága. Nyíregyháza helyzete még ettől is roszszabb képet mutat.

Hasonlóság látszik a szegénység társadalmi és demográfiai jellemzői mentén is, de az uniós átlagpolgár kockázatviselési aránya kisebb, mint a magyarországi, és a nyíregyházi polgáré. További eltérést mutat a jövedelmi helyzet, ahol már sem tendenciájában, sem kiterjedtségében nem láthatók hasonló arányok az egyes adatközlök között. Az Európai Unióban a megfosztottságtól mentes jövedelmi szegénység van inkább jelen, feleannyira jellemző a súlyos anyagi depriváció, és harmada azok aránya, akik a kirekesztettség két kockázatával együttesen rendelkeznek, vagyis kevésbé jellemző, hogy a szegénység egyben a társadalomból való kiszakadást is jelentené. Ettől jelentősen eltérnek a hazai adatok. A súlyos anyagi depriváció aránya többszörösen nagyobb kiterjedtséget mutat a „,csak” jövedelmi szegényekhez képest, és ez utóbbihoz viszonyítva, a jövedelmi szegénység és súlyos anyagi depriváció együttes jelenléte is magasabb. Számokban kifejezve: Magyarországon, a tartós megfosztottság aránya mintegy $15 \%$ körüli, és azok, akik a jövedelmi szegénységet is elszenvedik, 
további 5\%-ot képeznek. Nyíregyházán ezek az arányok 25\%, illetve 10\% körüli értékben van jelen.

A tanulmányban két törésvonal érhető tetten, mely a társadalmi kirekesztettség kérdésében jelentőséggel bírhat, és nem csupán Nyíregyháza esetében. Az egyik a „csak” háromszoros megfosztottság és a súlyos anyagi depriváció között húzódik, míg a másik a „,csak” súlyos anyagi depriváció jelenléte és a jövedelmi szegénységgel párosuló anyagi megfosztottság között. A „csak” állapotoknak a megismerése fényt deríthet arra, hogy ezek átmeneti ki- illetve belépéseket jelentenek, vagy tartóssá válva a kirekesztettség kockázatát növelik.

\section{Felhasznált irodalom}

1. Európai Bizottság (2010): A Bizottság közleménye az Európai Parlamentnek, a Tanácsnak, az Európai Gazdasági és Szociális Bizottságnak, és a Régiók Bizottságának. A szegénység és társadalmi kirekesztés elleni küzdelem európai platformja. A szociális és területi kohézió európai keretrendszere. COM (2010) 758 végleges. SEC (2010) 1564 végleges. HU, Brüsszel.

http://eur-lex.europa.eu/LexUriServ/LexUriServ.do?uri=COM:2010: 0758:FIN:HU:PDF

2. Fábián G., Takács P. (2012): A jövedelmi egyenlőtlenségek változásai és a szegénység. In: Fábián G., Patyán L., Huszti É. (szerk.): Életminőség Nyíregyházán 2008-2010.Nyíregyháza. Debreceni Egyetem, Orvos- és Egészségtudományi Centrum, Egészségügyi Kar. 33-48.

3. Fábián G., Takács P., Szigeti F. (2014): A jövedelmi helyzet változása, a társadalmi polarizálódás jellemzői Nyíregyháza városában (jelen kötetben).

4. Ferge Zs. (2005): Ellenálló egyenlőtlenségek. Esély, 4. 3-41.

5. Fusco A., Guio A.-C., Marlier E. (2010): Income poverty and material deprivation in European countries. Eurostat Methodologies and working papers. Luxembourg. Publications Office of the European Union.

6. http://epp.eurostat.ec.europa.eu/cache/ITY_OFFPUB/KS-RA-10030/EN/KS-RA-10-030-EN.PDF

7. Gábos A., Szívós P., Tátrai A. (2013): Szegénység és társadalmi kirekesztettség Magyarországon, 2000-2012. In: Szívós P., Tóth I. GY. (szerk.): Egyenlőtlenség és polarizálódás a magyar társadalomban. Budapest TÁRKI Monitorjelentések 2012. 37-60. 
8. Guio A. C. (2009): What can be learned from deprivation indicators in Europe. Eurostat Methodologies and working papers. Luxemburg. Publications Office of the European Union.

9. http://epp.eurostat.ec.europa.eu/cache/ITY_OFFPUB/KS-RA-09007/EN/KS-RA-09-007-EN.PDF

10. Havasi É. (2002): Szegénység és társadalmi kirekesztettség a mai Magyarországon. Szociológiai szemle, 4. 51-71.

11. Havasi É. (2006): Megélhetési nehézségek, anyagi depriváció. In: Szívós P., Tóth I.Gy. (szerk.): Feketén, fehéren. Budapest. TÁRKI Monitorjelentések 2005. 59-78.

12. Havasi É. (2008): Nem csak a pénz... megélhetési nehézségek, anyagi depriváció. In: Szívós P., Tóth I. Gy. (szerk.): Köz, teher, elosztás. Budapest. TÁRKI Monitorjelentések 2008. 61-71.

13. Spéder ZS. (2002): A szegénység változó arcai - Tények és értelmezések. Andorka Rudolf Társadalomtudományi Társaság - Századvég Kiadó. Budapest.

14. Szilicsány É. P. (2009): Életkörülmények Nyíregyházán a jövedelem, szegénység, fogyasztás tükrében. Szakdolgozat. Nyíregyháza. Debreceni Egyetem Egészségügyi Kar.

15. Szilicsány É. P. (2013): Helyzetkép a szegénységről és társadalmi kirekesztettségről Nyíregyházán, 2012. évben. Szakdolgozat. Nyíregyháza. Debreceni Egyetem Egészségügyi Kar.

16. Tóth I. GY.(2006): Jövedelemeloszlás 1987 és 2005 között. In: KOLOSI T., Tóth I. GY., Vukovich Gy. (szerk.): Társadalmi riport 2006. Budapest. TÁRKI 42-64.

\section{Internetes portálok:}

Internet1

http://appsso.eurostat.ec.europa.eu/nui/show.do?dataset=ilc_sip8\&lang=en (látogatás:2013.07.15.)

Internet2

http://epp.eurostat.ec.europa.eu/tgm/refreshTableAction.do?tab=table\&plugin=1

\&pcode $=$ t2020_53\&language $=$ en

\section{Szilicsány Éva Panna:}

Debreceni Egyetem Egészségügyi Kar, 4400 Nyíregyháza, Sóstói u. 2-4. 
